J. Amer. Soc. Hort. Sci. 115(1):83-89. 1990.

\title{
Nitrogen Form and Solution pH Influence Growth and Nutrition of Two Vaccinium Clones
}

\author{
Carl J. Rosen', Deborah L. Allan ${ }^{1}$, and James J. Luby ${ }^{2}$ \\ University of Minnesota, St. Paul, MN 55108 \\ Additional index words. blueberry, cranberry, ammonium, nitrate, X-ray microanalysis, soil nitrogen
}

\begin{abstract}
The effects of $\mathrm{pH}$ and $\mathrm{N}$ form on growth and nutrition of blueberry (Vaccinium corymbosum $\mathbf{L}$. $\mathrm{x}$. angustifolium Ait. CV. Northblue) and cranberry ( $V$. macrocarpon Ait. CV. Searles) were tested in separate greenhouse hydroponic experiments. A factorial treatment arrangement of two $\mathrm{pH}$ levels $(4.5$ and 6.5$)$ and three $\mathrm{N}_{\text {forms }}\left(\mathrm{NO}_{3}-\right.$ $\mathrm{N}, \mathrm{NH}_{4}-\mathrm{N}$, and $\mathrm{NH}_{4}-\mathrm{N} / \mathrm{NO}_{3}-\mathrm{N}$ ) was used for each clone. Blueberry shoot growth and final dry weight were greatest at $\mathbf{p H} 4.5$, regardless of $\mathrm{N}$ form. In contrast, cranberry fresh weight accumulation and final dry weight were higher with $\mathrm{NH}_{4}-\mathrm{N} / \mathrm{NO}_{3}-\mathrm{N}$ or $\mathrm{NH}_{4}-\mathrm{N}$ than with $\mathrm{NO}_{3}-\mathrm{N}$ alone. Cranberry plants receiving $\mathrm{NO}_{3}-\mathrm{N}$ alone accumulated low levels of tissue $\mathrm{N}$ and grew relatively poorly at both $\mathrm{pH}$ levels. Differences in $\mathrm{N}$ response by these two species may be due partially to the environments in which they were selected. Soil from the site where 'Northblue' blueberry was selected contained relatively high $\mathrm{NO}_{3}-\mathrm{N}$ and low $\mathrm{NH}_{4}-\mathrm{N}$ levels; soil from commercial 'Searles' cranberry bogs had relatively low $\mathrm{NO}_{3}-\mathrm{N}$ and high $\mathrm{NH}_{4}-\mathrm{N}$ levels. Both species accumulated relatively high levels of root $\mathrm{Fe}$, regardless of $\mathrm{pH}$ or $\mathrm{N}$ form. Levels of $\mathrm{Fe}$ in the root were as much as 100 times higher than in the shoot. Based on $\mathrm{X}$-ray microanalysis of cranberry roots, most of the Fe appeared to be precipitated on the root surface as iron phosphate. Concentrations of $\mathrm{Mn}$ in shoots and roots depended on $\mathrm{N}$ form and $\mathrm{pH}$. In general, root $\mathrm{Mn}$ was highest at pH 6.5 and apparently was precipitated with $\mathrm{Fe}$.
\end{abstract}

Most Ericaceous plants are native to acidic soil environments where low vitrification rates cause $\mathrm{NH}_{4}-\mathrm{N}$ to be the dominant $\mathrm{N}$ form available to plant roots (Rorison, 1986). Response of blueberry and cranberry to $\mathrm{NO}_{3}-\mathrm{N}$ and $\mathrm{NH}_{4}-\mathrm{N}$ nutrition has been variable. In some studies (Cain, 1952; Greidanus et al., 1972; Peterson et al., 1988; Townsend, 1967, 1969), $\mathrm{NH}_{4}-\mathrm{N}$ was su-

\footnotetext{
Received for publication 14 Oct. 1988. Paper no. 16,459 of the Scientific Journal Series, Minnesota Agricultural Experiment Station. We thank Elden Stang for providing the cranberry cuttings, Christine Searles for assistance with collecting the soil samples, and Gilbert Ahlstrand for assistance with X-ray microanalysis. The cost of publishing this paper was defrayed in part by the payment of page charges. Under postal regulations, this paper therefore must be hereby marked advertisement solely to indicate this fact.

'Assistant Professor, Dept. of Soil Science.

${ }^{2}$ Associate Professor, Dept. of Horticultural Science and Landscape Architec-
} ture. perior to $\mathrm{NO}_{3}-\mathrm{N}$ in promoting growth, while in others there was no difference (Dirr, 1974; Hammett and Ballinger, 1972; Oertli, 1963). Failure to control $\mathrm{pH}$ and vitrification in the medium may partially contribute to variable results. Hammett and Ballinger (1972), for example, noted that highbush blueberries grew as well on $\mathrm{NO}_{3}-\mathrm{N}$ as on $\mathrm{NH}_{4}-\mathrm{N}$ when the $\mathrm{pH}$ was $<6.2$. Genotypic differences in $\mathrm{NO}_{3}-\mathrm{N}$ use within the Vaccinium genus may also account for some of the variation. Cranberries appear to grow better with $\mathrm{NH}_{4}-\mathrm{N}$ than $\mathrm{NO}_{3}-\mathrm{N}$ and generally grow poorly when supplied with $\mathrm{NO}_{3}-\mathrm{N}$ alone (Greidanus et al., 1972). However, beneficial effects of $\mathrm{NO}_{3}-\mathrm{N}$ have also been demonstrated (Leschyson and Eaton, 1971), especially when solution $\mathrm{pH}$ is in the acid range (Addoms and Mounce, 1932).

Growth rates of most non-Ericaceous plants supplied with $\mathrm{NH}_{4}-\mathrm{N}$ as the sole form of $\mathrm{N}$ are generally reduced compared to those provided with $\mathrm{NO}_{3}-\mathrm{N}$, unless $\mathrm{pH}$ is strictly maintained 
between 5.7-6.1 (Peet et al., 1985; Rufty et al., 1983). Vaccinium spp. appear to be tolerant of $\mathrm{NH}_{4}-\mathrm{N}$, even at pH levels between 4.0-5.0. Precise mechanisms for $\mathrm{NH}_{4}-\mathrm{N}$ tolerance by Vaccinium are not known, but maybe related to a lower cation requirement or a greater ability to synthesize organic acids in the absence of $\mathrm{NO}_{3}-\mathrm{N}$ compared to non-tolerant plants (Salsac et al., 1987).

The objective of the present experiments was to use hydroponic culture to characterize the effects of $\mathrm{pH}$ and $\mathrm{N}$ form on growth, nutrition, and root chemical properties of blueberry and cranberry. As the cranberry experiment was not conducted the same year as the blueberry experiment, the effects of yearly climatological differences may bias direct interspecific comparisons. Therefore, differences in direction of responses, not in degree of response or absolute numerical variation, will be presented and discussed.

\section{Materials and Methods}

The first experiment was conducted with 'Northblue', a halfhigh blueberry clone, propagated from tissue culture. Plantlets were transferred to 0.43 -liter pots containing acid peat and then maintained in the greenhouse for $\approx: 2$ months.

To initiate the solution culture phase of the experiment, plant roots were thoroughly rinsed in distilled water to remove adhering peat. Each plant was then transferred to a black plastic pot containing 7 liters of a nitrogen-deficient background nutrient solution of the following composition (in $\mathrm{mM}$ ): $\mathrm{CaSO}_{4} \cdot 2 \mathrm{H}_{2} \mathrm{O}, 1.0 ; \mathrm{MgSO}_{4} \cdot 7 \mathrm{H}_{2} \mathrm{O}, 0.75 ; \mathrm{K}_{2} \mathrm{SO}_{4}, 0.5 ; \mathrm{Ca}\left(\mathrm{H}_{2} \mathrm{PO}_{4}\right)_{2}$, 0.13; (in $\mu \mathrm{M}$ ), FeNaEDTA, 80; $\mathrm{H}_{3} \mathrm{BO}_{3}, 46 ; \mathrm{MnCl}_{2} \cdot 4 \mathrm{H}_{2} \mathrm{O}$, 9; $\mathrm{ZnSO}_{4} \cdot 7 \mathrm{H}_{2} \mathrm{O}, 0.8 ; \mathrm{CuSO}_{4} \cdot 5 \mathrm{H}_{2} \mathrm{O}, 0.3 ; \mathrm{H}_{2} \mathrm{MoO}_{4} \cdot \mathrm{H}_{2} \mathrm{O}, 0.1$, adjusted to a $\mathrm{pH}$ of 4.5 . Nitrogen was then adjusted in the background solution to $2 \mathrm{~mm}$ using $\mathrm{NH}_{4} \mathrm{NO}_{3}$ as the $\mathrm{N}$ form. Plants were maintained in this solution for 6 weeks to allow initiation of new roots. Solutions were continuously aerated. Greenhouse air temperatures were set for a 14-hr 28C day and a 10-hr 20C night.

Treatments were initiated by transferring plants to the background nutrient solution containing $\mathrm{NH}_{4}-\mathrm{N}$ alone, $\mathrm{NH}_{4}-\mathrm{N}$ and $\mathrm{NO}_{3}-\mathrm{N}$, or $\mathrm{NO}_{3}-\mathrm{N}$ alone in factorial combination with $\mathrm{pH}$ treatments of 4.5 and 6.5. A randomized complete block design was used with four replications. All $\mathrm{N}$ levels were adjusted to $2 \mathrm{~mm}$ using $\left(\mathrm{NH}_{4}\right) \mathrm{SO}_{4}$ in the $\mathrm{NH}_{4}-\mathrm{N}$-alone solution, $\mathrm{NH}_{4} \mathrm{NO}_{3}$ in the $\mathrm{NH}_{4}-\mathrm{N} / \mathrm{NO}_{3}-\mathrm{N}$ solution and $\mathrm{Ca}\left(\mathrm{NO}_{3}\right)_{2}$ in the $\mathrm{NO}_{3}-\mathrm{N}$-alone solution. Calcium sulfate was omitted in the $\mathrm{NO}_{3}-\mathrm{N}$-alone background solution to keep initial Ca levels equal. Therefore, to vary $\mathrm{N}$ source, sulfate was also varied: $3.25 \mathrm{~mm}$ in the $\mathrm{NH}_{4}$ $\mathrm{N}$-alone solution, $2.25 \mathrm{~mm}$ in the $\mathrm{NH}_{4}-\mathrm{N} / \mathrm{NO}_{3}-\mathrm{N}$ solution, and $1.25 \mathrm{~mm}$ in the $\mathrm{NO}_{3}-\mathrm{N}$ solution. Solutions were changed every 14 days and $\mathrm{pH}$ was adjusted daily using $\mathrm{Ca}(\mathrm{OH})_{2}$ or $\mathrm{H}_{2} \mathrm{SO}_{4}$. A nitrification inhibitor, 2-chloro-6-(trichloromethyl) pyridine (nitrapyrin), was added to all solutions at the rate of $4 \mu \mathrm{M}$, which successfully inhibited conversion of $\mathrm{NH}_{4}-\mathrm{N}$ to $\mathrm{NO}_{3}-\mathrm{N}$. During the course of the experiment, $\mathrm{NO}_{3}-\mathrm{N}$ and $\mathrm{NH}_{4}-\mathrm{N}$ levels were determined using conductimetric procedures (Carlson, 1978; 1986) before changing solutions.

Treatments were initiated 8 Feb. 1985 and the experiment was terminated in 12 Oct. 1985 . Shoot length was periodically measured during the experiment. At harvest, shoots were detached from roots. Roots were rinsed in deionized water for $\approx 10 \mathrm{sec}$ and blotted dry on paper towels. Shoots and roots were dried at $60 \mathrm{C}$ for 3 days and dry weights were recorded. Dried shoots and roots were ground in a Wiley mill to pass through a 40-mesh screen. Dried samples were digested in concentrated
$\mathrm{H}_{2} \mathrm{SO}_{4}$ and Kjeldahl $\mathrm{N}$ was determined using conductimetric procedures (Carlson, 1978). After ashing and resuspending in $2 \mathrm{~N} \mathrm{HCl}$, other elements were determined using an inductively coupled plasma spectrometer (Munter et al., 1984).

In a second experiment, with the cranberry clone 'Searles', stem cuttings were rooted directly in 1-liter jars containing the same solution described above for rooting blueberry. Solutions were continuously aerated and adjusted to $\mathrm{pH} 4.5$ daily. After roots were initiated ( 6 weeks), plants were transferred to black plastic pots containing 7 liters of nutrient solution. Treatments were the same as those described for the blueberry experiment. A randomized complete block design was used with four replications. As for blueberries, nitrapyrin was used to inhibit nitrification. Treatments were initiated 22 Apr. 1987 and the experiment was terminated 30 Sept. 1987. Fresh weight of each plant was recorded at monthly intervals.

Cranberry plants were harvested in a similar manner as described for the blueberries, except that subsamples $(\approx 1 \mathrm{~g})$ of fresh root tips were collected, frozen in liquid $\mathrm{N}_{2}$, and stored at $-70 \mathrm{C}$ for subsequent $\mathrm{x}$-ray microprobe analysis.

For $\mathrm{x}$-ray microanalysis, the frozen cranberry root samples were freeze-dried and mounted onto aluminum stubs covered with double-stick tape. Carbon paint was used to further secure the root samples onto the stub. Samples were then transferred to a vacuum evaporator and coated with nickel. All observations were made with a Phillips 500X SEM and an EDAX 711F energy dispersive $\mathrm{x}$-ray analysis unit. The incident $12-\mathrm{KeV}$ electron beam was standardized for each stub by focusing onto an exposed Al margin and adjusted using the beam spot size control until 3000 counts per second of Al X-rays plus background were obtained. X-ray spectra were collected from crystal-like particles on the root surface as well as from epidermal cell surfaces. Counts per $80 \mathrm{sec}$ were recorded as a relative measure of nutrient level.

Soil samples (0- to $15-\mathrm{cm}$ and $15-$ to $30-\mathrm{cm}$ depths) were collected from the site where the original 'Northblue' blueberry plant was selected in Becker, Minn., and from several 'Searles' cranberry plantings near Wisconsin Rapids, Wis. Samples from both locations were collected the first week in May and the first week in June. The soil collected at Becker was a Hubbard loamy sand (Udorthenic Haploborolls) and that collected at Wisconsin Rapids was a Markey muckey peat (Terric Borosaprists) overlaid with a Newson sand (Humaqueptic Psammaquents). Samples were kept moist and cool (4C) before analysis. Nitrate-N and $\mathrm{NH}_{4}-\mathrm{N}$ were determined in 1 soil $: 52-\mathrm{N} \mathrm{KCl} \mathrm{(w/v)} \mathrm{extracts}$ using conductimetric procedures (Carlson, 1978, 1986). Percent moisture in the samples was determined and results expressed on a dry-weight basis.

\section{Results}

Blueberry and cranberry growth. Blueberry growth was affected more by $\mathrm{pH}$ of the nutrient solution than by $\mathrm{N}$ form (Table 1). By 210 days after treatment initiation, shoots were about three times longer in plants growing in solutions adjusted to $\mathrm{pH}$ 4.5 than to 6.5 . In the $\mathrm{pH} 6.5$ treatment, plants appeared stunted, although the leaves generally were green with no signs of chlorosis. Roots in the high $\mathrm{pH}$ medium were dark and stunted regardless of $\mathrm{N}$ form. In the low-pH medium, roots were white with $\mathrm{NH}_{4}-\mathrm{N}$, gray-brown with $\mathrm{NO}_{3}-\mathrm{N}$, and intermediate with the mixture. Nitrogen form did not have a significant effect on shoot and root dry weight, although growth was numerically highest with the combination of $\mathrm{N}$ forms. 'Northblue' blueber- 
Table 1. Solution $\mathrm{pH}$ and $\mathrm{N}$ form effects on 'Northblue' blueberry shoot length and final shoot and root dry wt.

\begin{tabular}{|c|c|c|c|c|c|}
\hline \multirow[b]{4}{*}{ Variable } & \multicolumn{5}{|c|}{ Days after treatment initiation } \\
\hline & \multirow[b]{2}{*}{0} & \multirow[b]{2}{*}{105} & \multirow[b]{2}{*}{210} & \multicolumn{2}{|c|}{246} \\
\hline & & & & \multicolumn{2}{|c|}{ Dry wt $(\mathrm{g})$} \\
\hline & \multicolumn{3}{|c|}{ Shoot length $(\mathrm{cm})$} & Shoot & Root \\
\hline \multicolumn{6}{|l|}{$\mathrm{N}$ form } \\
\hline $\mathrm{NH}_{4}$ & 38.3 & 63.9 & 127.3 & 19.61 & 4.71 \\
\hline $\mathrm{NH}_{4} / \mathrm{NO}_{3}$ & 39.4 & 83.3 & 193.0 & 28.63 & 9.42 \\
\hline $\mathrm{NO}_{3}$ & 34.4 & 73.3 & 163.1 & 24.54 & 6.39 \\
\hline Significance & NS & NS & NS & NS & NS \\
\hline \multicolumn{6}{|l|}{$\mathrm{pH}$} \\
\hline 4.5 & 37.1 & 88.8 & 237.4 & 37.21 & 11.71 \\
\hline 6.5 & 37.1 & 58.2 & 84.9 & 11.30 & 1.98 \\
\hline Significance & NS & $*$ & $*$ & $* *$ & $* *$ \\
\hline
\end{tabular}

NS,*,** Nonsignificant or significant at $P=0.05$ or 0.01 , respectively. The interaction was nonsignificant in all cases.

ries appear to be able to use either $\mathrm{NO}_{3}-\mathrm{N}$ or $\mathrm{NH}_{4}-\mathrm{N}$ and grow best when the $\mathrm{pH}$ of the medium is in the acid range.

In contrast to blueberry, cranberry growth was affected more by $\mathrm{N}$ form than by $\mathrm{pH}$ (Table 2). Fresh and dry weight yields were significantly depressed when $\mathrm{NO}_{3}-\mathrm{N}$ was the sole form of $\mathrm{N}$. However, fresh weight and final dry weight were greatest when $\mathrm{NO}_{3}-\mathrm{N}$ plus $\mathrm{NH}_{4}-\mathrm{N}$ was provided at either $\mathrm{pH}$. Root color was affected by $\mathrm{N}$ form and $\mathrm{pH}$. Ammonium-N grown plants had light gray roots at $\mathrm{pH} 4.5$ and were much darker at 6.5. Nitrate-N grown plants had brown-gray roots at 4.5 and black stunted roots at 6.5. At each respective $\mathrm{pH}, \mathrm{NH}_{4}-\mathrm{N}$ plus $\mathrm{NO}_{3}$ $\mathrm{N}$-grown plants had roots that were slightly darker than roots of plants grown in $\mathrm{NH}_{4}-\mathrm{N}$ alone. Root dry weight was lower at $\mathrm{pH} 6.5$ than at 4.5, although shoot dry weight was apparently unaffected by $\mathrm{pH}$.

Nutrient concentrations in shoots. Nutrient levels in blueberry and cranberry shoots are presented in Tables 3 and 4. Nitrogen concentrations in both blueberry and cranberry were significantly lower in the $\mathrm{NO}_{3}-\mathrm{N}$ treatments than in the $\mathrm{NH}_{4}-\mathrm{N}$ treatments. Since stems and leaves were combined for nutrient analysis, relatively low $\mathrm{N}$ concentrations were observed in all treatments. For both species, $\mathrm{Ca}$ and $\mathrm{Mg}$ concentrations were highest for the $\mathrm{NO}_{3}-\mathrm{N}$ treatment, while $\mathrm{pH}$ had a variable effect. Nitrogen form had no effect on K levels; however, shoot K was greater at $\mathrm{pH} 4.5$ than at 6.5. Phosphorus levels were highest in cranberry shoots when plants were provided with $\mathrm{NH}_{4}-\mathrm{N}$. Levels of $\mathrm{P}$ in blueberry shoots were not significantly affected by $\mathrm{N}$ form. Shoot Fe levels were not affected by $\mathrm{pH}$ or $\mathrm{N}$ source in blueberry, but lower $\mathrm{Fe}$ in cranberry shoots was associated with higher solution $\mathrm{pH}$. Zinc, $\mathrm{Cu}$, and $\mathrm{B}$ concentrations in blueberry shoots were not affected by $\mathrm{pH}$ or $\mathrm{N}$ source. Cranberry in high $\mathrm{pH}$ and $\mathrm{NO}_{3}-\mathrm{N}$ treatments had the lowest shoot concentrations of $\mathrm{B}$ and $\mathrm{Zn}$. Significant $\mathrm{pH} \times \mathrm{N}$ from interactions occurred with both species for Mn levels (Table 5). In general, shoot $\mathrm{Mn}$ was higher at low $\mathrm{pH}$ than at high $\mathrm{pH}$. For cranberries, $\mathrm{Mn}$ was higher with $\mathrm{NO}_{3}-\mathrm{N}$ than with $\mathrm{NH}_{4}-\mathrm{N}$. For blueberries, there was no distinct $\mathrm{Mn}$ effect associated with $\mathrm{N}$ form.

Nutrient concentrations in roots. Concentrations of $\mathrm{N}$ in blueberry and cranberry roots were lower in the $\mathrm{NO}_{3}-\mathrm{N}$ treatment than treatments that included $\mathrm{NH}_{4}-\mathrm{N}$ (Tables 6 and 7). Solution $\mathrm{pH}$ had no effect on root $\mathrm{N}$ concentrations. Levels of $\mathrm{K}$ in blueberry roots increased with lower $\mathrm{pH}$, while, in cranberry, root $\mathrm{K}$ levels were highest with the $\mathrm{NO}_{3}-\mathrm{N} / \mathrm{NH}_{4}-\mathrm{N}$ treatment, regardless of $\mathrm{pH}$. Root $\mathrm{Ca}$ concentrations increased with $\mathrm{pH}$ and were highest with $\mathrm{NO}_{3}-\mathrm{N}$. In blueberries, root $\mathrm{Mg}$ levels were highest with $\mathrm{NO}_{3}-\mathrm{N}$. In contrast, root $\mathrm{Mg}$ in cranberries increased with increasing $\mathrm{pH}$, but $\mathrm{N}$ form had no effect. Increasing solution $\mathrm{pH}$ had a strong effect on increasing root Mn levels in both species. Root $\mathrm{Mn}$ tended to increase with nitrate, although, for blueberry, increases were greater at $\mathrm{pH} 6.5$ than at $\mathrm{pH} 4.5$, which accounted for the significant $\mathrm{N}$ form $\times \mathrm{pH}$ interaction (Table 5). Root Fe levels were $\approx 100$ to 200 times higher than shoot Fe levels. In blueberry, highest Fe levels were associated with $\mathrm{NH}_{4}-\mathrm{N}$, regardless of $\mathrm{pH}$, while, in cranberry, root $\mathrm{Fe}$ was highest at $\mathrm{pH} 4.5$, regardless of $\mathrm{N}$ form.

Ammonium and nitrate uptake. Solution $\mathrm{NO}_{3}-\mathrm{N}$ and $\mathrm{NH}_{4}-\mathrm{N}$ concentrations were determined every 2 weeks before a solution change. In general, blueberry plants depleted all $\mathrm{NO}_{3}-\mathrm{N}$ and $\mathrm{NH}_{4}-\mathrm{N}$ from low-pH solutions within the 2 weeks. Because of slower growth in the high-pH treatments, most of the $\mathrm{NO}_{3}-\mathrm{N}$ and $\mathrm{NH}_{4}-\mathrm{N}$ remained in solution after the same 2 weeks. In contrast, cranberries depleted $\mathrm{NH}_{4}-\mathrm{N}$ to the same extent from both high- and low-pH solutions; however, depletion of nitrate

Table 2. Solution $\mathrm{pH}$ and $\mathrm{N}$ form effects on 'Searless' cranberry fresh weight accumulation and final shoot and root dry wt.

\begin{tabular}{|c|c|c|c|c|c|c|c|c|}
\hline \multirow[b]{4}{*}{ Variable } & \multicolumn{8}{|c|}{ Days after treatment initiation } \\
\hline & \multirow{3}{*}{0} & \multirow{3}{*}{28} & \multirow[b]{2}{*}{69} & \multirow[b]{2}{*}{97} & \multirow{3}{*}{126} & \multirow{3}{*}{155} & \multirow{2}{*}{\multicolumn{2}{|c|}{$\frac{161}{\text { Dry wt (g) }}$}} \\
\hline & & & & & & & & \\
\hline & & & \multicolumn{2}{|c|}{ Fresh wt $(\mathrm{g})$} & & & Shoot & Root \\
\hline \multicolumn{9}{|l|}{$\overline{N \text { form }}$} \\
\hline $\mathrm{NH}_{4}$ & 1.4 & 4.6 & 16.5 & 29.1 & 47.3 & 51.7 & 16.08 & 1.10 \\
\hline $\mathrm{NH}_{4} / \mathrm{NO}_{3}$ & 1.2 & 3.9 & 14.5 & 27.8 & 54.7 & 69.7 & 22.04 & 1.54 \\
\hline $\mathrm{NO}_{3}$ & 1.0 & 2.8 & 10.0 & 17.1 & 27.1 & 31.2 & 8.94 & 1.35 \\
\hline Significance & NS & NS & NS & $*$ & $* *$ & $* *$ & $* *$ & $*$ \\
\hline LSD $(0.05)$ & -- & $\cdots$ & --- & 10.6 & 14.1 & 12.7 & 4.4 & 0.3 \\
\hline \multicolumn{9}{|l|}{$\mathrm{pH}$} \\
\hline 4.5 & 1.3 & 4.2 & 14.5 & 27.9 & 45.8 & 54.5 & 16.45 & 1.50 \\
\hline 6.5 & 1.2 & 3.4 & 10.3 & 21.4 & 40.2 & 47.1 & 14.92 & 1.15 \\
\hline Significance & NS & NS & NS & NS & NS & NS & NS & $*$ \\
\hline
\end{tabular}


Table 3. Solution $\mathrm{pH}$ and $\mathrm{N}$ form effects on elemental composition of 'Northblue' blueberry shoots.

\begin{tabular}{|c|c|c|c|c|c|c|c|c|c|c|c|}
\hline \multirow[b]{3}{*}{ Variable } & \multicolumn{11}{|c|}{ Elemental composition (dry-wt basis) } \\
\hline & $\mathrm{N}$ & $P$ & $\mathrm{~K}$ & $\mathrm{Ca}$ & $\mathrm{Mg}$ & $\mathrm{Fe}$ & $\mathrm{Al}$ & $\mathrm{Mn}$ & $\mathrm{Zn}$ & $\mathrm{Cu}$ & $\mathrm{B}$ \\
\hline & \multicolumn{5}{|c|}{$\left(\mathrm{g} \cdot \mathrm{kg}^{-1}\right)$} & \multicolumn{6}{|c|}{$\left(\mathrm{mg} \cdot \mathrm{kg}^{-1}\right)$} \\
\hline \multicolumn{12}{|l|}{$\mathrm{N}$ form } \\
\hline $\mathrm{NH}_{4}$ & 13.7 & 1.70 & 3.33 & 2.45 & 0.99 & 125 & 29 & 373 & 37 & 4 & 38 \\
\hline $\mathrm{NH}_{4} / \mathrm{NO}_{3}$ & 11.0 & 1.54 & 3.39 & 2.89 & 1.01 & 100 & 26 & 278 & 37 & 5 & 45 \\
\hline $\mathrm{NO}_{3}$ & 10.4 & 1.51 & 3.92 & 4.31 & 1.56 & 68 & 32 & 186 & 32 & 4 & 50 \\
\hline Significance & $* *$ & NS & NS & $* *$ & $* *$ & NS & NS & NS & NS & NS & NS \\
\hline $\operatorname{LSD}(0.05)$ & 1.5 & --- & --- & 0.67 & 0.23 & --- & -+ & $\cdots$ & --- & --- & -- \\
\hline \multicolumn{12}{|l|}{$\mathrm{pH}$} \\
\hline 4.5 & 11.4 & 1.51 & 3.99 & 3.39 & 1.16 & 77 & 30 & 404 & 34 & 4 & 47 \\
\hline 6.5 & 12.0 & 1.65 & 3.09 & 3.05 & 1.22 & 118 & 28 & 220 & 37 & 4 & 41 \\
\hline Significance & NS & NS & $*$ & NS & NS & NS & NS & $* *$ & NS & NS & NS \\
\hline $\mathrm{pH} \times \mathrm{N}$ form & & & & & & & & & & & \\
\hline Significance & NS & NS & NS & NS & $*$ & NS & NS & $*$ & NS & NS & NS \\
\hline
\end{tabular}

Ns,*,**Nonsignificant or significant at $P=0.05$ or 0.01 , respectively.

Table 4. Solution $\mathrm{pH}$ and $\mathrm{N}$ form effects on elemental composition of 'Searles' cranberry shoots.

\begin{tabular}{|c|c|c|c|c|c|c|c|c|c|c|c|}
\hline \multirow[b]{3}{*}{ Variable } & \multicolumn{11}{|c|}{ Elemental composition (dry-wt basis) } \\
\hline & $\mathrm{N}$ & $\mathbf{P}$ & $\mathrm{K}$ & $\mathrm{Ca}$ & $\mathrm{Mg}$ & $\mathrm{Fe}$ & $\mathrm{Al}$ & $\mathrm{Mn}$ & $\mathrm{Zn}$ & $\mathrm{Cu}$ & $\mathrm{B}$ \\
\hline & \multicolumn{5}{|c|}{$\left(\mathrm{g} \cdot \mathrm{kg}^{-1}\right)$} & \multicolumn{6}{|c|}{$\left(\mathrm{mg} \cdot \mathrm{kg}^{-1}\right)$} \\
\hline \multicolumn{12}{|l|}{$\mathrm{N}$ form } \\
\hline $\mathrm{NH}_{4}$ & 15.0 & 2.02 & 6.65 & 3.96 & 1.43 & 76 & 32 & 132 & 22 & 4 & 80 \\
\hline $\mathrm{NH}_{4} / \mathrm{NO}_{3}$ & 14.1 & 1.80 & 6.84 & 4.31 & 1.19 & 71 & 30 & 170 & 22 & 4 & 77 \\
\hline $\mathrm{NO}_{3}$ & 6.4 & 1.07 & 6.37 & 5.34 & 1.36 & 75 & 28 & 338 & 19 & 4 & 65 \\
\hline Significance & $* *$ & $* *$ & NS & $* *$ & $* *$ & NS & NS & $* *$ & $*$ & NS & $* *$ \\
\hline LSD $(0.05)$ & 2.0 & 0.31 & -- & 0.32 & 0.13 & --- & $\cdots$ & 39 & 2 & --- & 7 \\
\hline \multicolumn{12}{|l|}{$\mathrm{pH}$} \\
\hline 4.5 & 12.1 & 1.69 & 6.99 & 4.26 & 1.26 & 86 & 32 & 234 & 23 & 5 & 78 \\
\hline 6.5 & 1.16 & 1.57 & 6.24 & 4.82 & 1.40 & 61 & 27 & 192 & 19 & 4 & 70 \\
\hline Significance & $\mathrm{NS}$ & NS & $*$ & $* *$ & NS & $* *$ & NS & * & $* *$ & NS & $*$ \\
\hline $\mathrm{pH} \times \mathrm{N}$ form & & & & & & & & & & & \\
\hline Significance & NS & NS & NS & NS & NS & NS & NS & $*$ & NS & NS & $* *$ \\
\hline
\end{tabular}

Table 5. Manganese concentrations in 'Northblue' blueberry and 'Searles' cranberry roots and shoots as affected by $\mathrm{pH}$ and $\mathrm{N}$ form interaction.

\begin{tabular}{|c|c|c|c|c|c|}
\hline \multirow[b]{2}{*}{$\mathrm{pH}$} & \multirow[b]{2}{*}{$\mathrm{N}$ form } & \multicolumn{2}{|c|}{ Blueberry } & \multicolumn{2}{|c|}{ Cranberry } \\
\hline & & Roots & Shoots & Roots & Shoots \\
\hline \multirow[t]{3}{*}{4.5} & $\mathrm{NH}_{4}$ & 303 & 561 & 151 & 163 \\
\hline & $\mathrm{NH}_{4} / \mathrm{NO}_{3}$ & 544 & 302 & 138 & 158 \\
\hline & $\mathrm{NO}_{3}$ & 311 & 348 & 469 & 382 \\
\hline \multirow[t]{3}{*}{6.5} & $\mathrm{NH}_{4}$ & 1116 & 184 & 3523 & 101 \\
\hline & $\mathrm{NH}_{4} / \mathrm{NO}_{3}$ & 1042 & 253 & 2678 & 183 \\
\hline & $\mathrm{NO}_{3}$ & 3620 & 223 & 3304 & 294 \\
\hline \multicolumn{6}{|c|}{$\mathrm{pH} \times \mathrm{N}$ form } \\
\hline & cance & $* *$ & $* *$ & NS & * \\
\hline
\end{tabular}

from solution was slow, regardless of $\mathrm{pH}$. Within the 2 weeks between solution changes, neither $\mathrm{NH}_{4}-\mathrm{N}$ nor $\mathrm{NO}_{3}-\mathrm{N}$ was completely depleted from solution. In short-term depletion experiments with cranberry plants, $\mathrm{NH}_{4}-\mathrm{N}$ uptake rates were 30 to
100 times higher than corresponding $\mathrm{NO}_{3}-\mathrm{N}$ uptake rates (data not presented).

Changes in solution $\mathrm{pH}$. Although a relatively large volume of solution (7 liters) was used per plant, solution $\mathrm{pH}$ did not remain stable for more than $24 \mathrm{hr}$. Both species grown in solutions with $\mathrm{NH}_{4}-\mathrm{N}$ or $\mathrm{NH}_{4}-\mathrm{N}$ plus $\mathrm{NO}_{3}-\mathrm{N}$ initially decreased solution $\mathrm{pH}$ by 0.5 to $1.0 \mathrm{pH}$ unit. In contrast, blueberries grown in solutions with $\mathrm{NO}_{3}-\mathrm{N}$ alone at $\mathrm{pH} 4.5$ generally increased solution $\mathrm{pH}$ by 0.5 to $1.0 \mathrm{pH}$ unit. Blueberries grown in solutions with $\mathrm{NO}_{3}-\mathrm{N}$ alone at $\mathrm{pH} 6.5$ increased $\mathrm{pH}$ only slightly ( $<0.2 \mathrm{pH}$ unit). Cranberries supplied with $\mathrm{NO}_{3}-\mathrm{N}$ caused little change in solution $\mathrm{pH}$. The lack of $\mathrm{pH}$ change in the $\mathrm{NO}_{3}-\mathrm{N}$ only treatments with cranberry corresponds with low rates of $\mathrm{NO}_{3}-\mathrm{N}$ uptake.

\section{Discussion}

The lack of response by blueberry to $\mathrm{N}$ form in the present study agrees with results reported by Oertli (1963) and Hammett and Ballinger (1972), but contradicts other studies (Cain, 1952; Peterson et al., 1988; Townsend, 1967, 1969) where $\mathrm{NH}_{4}-\mathrm{N}$ was superior to $\mathrm{NO}_{3}-\mathrm{N}$ in promoting growth. Cranberry growth rate was lower when $\mathrm{NO}_{3}-\mathrm{N}$ was the sole form of $\mathrm{N}$ compared to when $\mathrm{NH}_{4}-\mathrm{N}$ or $\mathrm{NH}_{4}-\mathrm{N}$ plus $\mathrm{NO}_{3}-\mathrm{N}$ was supplied. Greidanus et al. (1972) reported that $\mathrm{NO}_{3}-\mathrm{N}$ was detrimental to cranberry growth and suggested that any growth in the $\mathrm{NO}_{3}-\mathrm{N}$ solutions was due to to $\mathrm{NO}_{3}-\mathrm{N}$ reduction by microorganisms before use by the cranberry. In the present experiments, $\mathrm{NO}_{3}-\mathrm{N}$ did not inhibit growth as long as $\mathrm{NH}_{4}-\mathrm{N}$ was also supplied. Moreover, cranberry plants supplied with both $\mathrm{NO}_{3}-\mathrm{N}$ and $\mathrm{NH}_{4}-\mathrm{N}$ accumulated more total shoot $\mathrm{N}$ (331 mg) than plants supplied with $\mathrm{NH}_{4}-\mathrm{N}$ alone $(241 \mathrm{mg})$ or $\mathrm{NO}_{3}-\mathrm{N}$ alone $(57 \mathrm{mg})$.

Nitrogen concentrations in cranberry shoots and roots were much lower in the $\mathrm{NO}_{3}-\mathrm{N}$ treatments than in the $\mathrm{NH}_{4}-\mathrm{N}$ treatments. Stieber and Peterson (1987) have reported that, when cranberry vines are starved of $\mathrm{N}$, active growth still occurred as a result of endogenous recycling of $\mathrm{N}$ when $\mathrm{N}$ concentrations in vines were as low as $5.5 \mathrm{~g} \cdot \mathrm{kg}^{-1}$. In this experiment, treatments were initiated when total plant fresh mass was $\approx 1 \mathrm{~g}$ and the final total fresh mass was $>30 \mathrm{~g}$. Because of this large increase in plant mass, more than endogenous $\mathrm{N}$ would be required to maintain growth for the 160-day duration of the experiment. The possibility does exist that microorganisms in solution played a role in $\mathrm{NO}_{3}-\mathrm{N}$ reduction before use by the cranberry. Although this issue cannot be resolved in the present experiments, low $\mathrm{NO}_{3}-\mathrm{N}$ uptake rates and low $\mathrm{N}$ accumulation in shoots provided only with $\mathrm{NO}_{3}-\mathrm{N}$ suggest that cranberry has a limited capacity for $\mathrm{NO}_{3}-\mathrm{N}$ uptake and metabolism. In blueberry, $\mathrm{N}$ concentrations in $\mathrm{NO}_{3}-\mathrm{N}$-grown plants were lower than $\mathrm{NH}_{4}-\mathrm{N}$-grown plants, but not as depressed as in cranberry. A combination of $\mathrm{NH}_{4}-\mathrm{N}$ and $\mathrm{NO}_{3}-\mathrm{N}$ appeared to be equal to or better than either form alone for blueberry and cranberry growth. This growth response suggests that $\mathrm{N}$ may be used more efficiently by these species if both $\mathrm{NH}_{4}-\mathrm{N}$ and $\mathrm{NO}_{3}-\mathrm{N}$ are provided. These results clearly indicate that $\mathrm{NO}_{3}-\mathrm{N}$ per se is not toxic to either species.

Responses to $\mathrm{N}$ form by these two Vaccinium clones may partially result from the conditions under which they were selected, a hypothesis suggested for cranberry by Greidanus et al. (1972). 'Northblue' blueberry resulted from crosses between $V$. angustifolium and $V$. corymbosum germplasm originally propagated and selected in a well-drained, sandy, acid soil in central Minnesota (Luby et al., 1986). 'Searles' cranberry is a selection made in 1903 from native vines growing in acid bogs (Stang 
Table 6. Solution $\mathrm{pH}$ and $\mathrm{N}$ form effects on elemental composition of 'Northblue' blueberry roots.

\begin{tabular}{|c|c|c|c|c|c|c|c|c|c|c|c|}
\hline \multirow[b]{3}{*}{ Variable } & \multicolumn{11}{|c|}{ Elemental composition (dry-wt basis) } \\
\hline & $\mathbf{N}$ & $\mathbf{P}$ & $\mathbf{K}$ & $\mathrm{Ca}$ & $\mathrm{Mg}$ & $\mathrm{Fe}$ & $\mathrm{Al}$ & $\mathrm{Mn}$ & $\mathrm{Zn}$ & $\mathrm{Cu}$ & $\mathrm{B}$ \\
\hline & \multicolumn{6}{|c|}{$\left(\mathrm{g} \cdot \mathrm{kg}^{-1}\right)$} & \multicolumn{5}{|c|}{$\left(\mathrm{mg} \cdot \mathrm{kg}^{-1}\right)$} \\
\hline \multicolumn{12}{|l|}{$\mathrm{N}$ form } \\
\hline $\mathrm{NH}_{4}$ & 22.1 & 6.96 & 3.43 & 3.62 & 1.07 & 13.06 & 184 & 709 & 56 & 40 & 10 \\
\hline $\mathrm{NH}_{4} / \mathrm{NO}_{3}$ & 21.6 & 6.02 & 3.65 & 5.10 & 1.53 & 8.37 & 159 & 793 & 55 & 39 & 12 \\
\hline $\mathrm{NO}_{3}$ & 16.9 & 6.66 & 4.13 & 5.99 & 1.96 & 6.69 & 173 & 1968 & 55 & 20 & 13 \\
\hline Significance & $*$ & NS & NS & $*$ & $* *$ & $*$ & NS & $* *$ & NS & $*$ & NS \\
\hline LSD $(0.05)$ & 4.2 &.- & --- & 1.69 & 0.34 & 4.93 & -- & 581 & --- & 10 & -- \\
\hline \multicolumn{12}{|l|}{$\mathrm{pH}$} \\
\hline 4.5 & 20.2 & 6.34 & 4.30 & 3.74 & 1.50 & 9.50 & 159 & 386 & 52 & 36 & 10 \\
\hline 6.5 & 20.2 & 6.75 & 3.17 & 6.06 & 1.53 & 9.26 & 185 & 1926 & 57 & 30 & 14 \\
\hline Significance & NS & NS & NS & $* *$ & NS & NS & NS & $* *$ & NS & NS & $*$ \\
\hline $\mathrm{pH} \times \mathrm{N}$ form & & & & & & & & & & & \\
\hline Significance & NS & NS & NS & NS & NS & NS & NS & $* *$ & NS & NS & NS \\
\hline
\end{tabular}

Table 7. Solution $\mathrm{pH}$ and $\mathrm{N}$ form effects on elemental composition of 'Searles' cranberry roots.

\begin{tabular}{|c|c|c|c|c|c|c|c|c|c|c|c|}
\hline \multirow[b]{3}{*}{ Variable } & \multicolumn{11}{|c|}{ Elemental composition (dry-wt basis) } \\
\hline & $\mathrm{N}$ & $\mathrm{P}$ & $\mathrm{K}$ & $\mathrm{Ca}$ & $\mathrm{Mg}$ & $\mathrm{Fe}$ & $\mathrm{Al}$ & $\mathrm{Mn}$ & $\mathrm{Zn}$ & $\mathrm{Cu}$ & B \\
\hline & \multicolumn{6}{|c|}{$\left(\mathrm{g} \cdot \mathrm{kg}^{-1}\right)$} & \multicolumn{5}{|c|}{$\left(\mathrm{mg} \cdot \mathrm{kg}^{-1}\right)$} \\
\hline \multicolumn{12}{|l|}{$\mathrm{N}$ form } \\
\hline $\mathrm{NH}_{4}$ & 21.5 & 12.9 & 5.29 & 6.38 & 1.83 & 13.0 & 346 & 1837 & 55 & 22 & 53 \\
\hline $\mathrm{NH}_{4} / \mathrm{NO}_{3}$ & 23.4 & 10.1 & 6.70 & 4.65 & 1.74 & 8.8 & 262 & 1408 & 49 & 16 & 24 \\
\hline $\mathrm{NO}_{3}$ & 11.2 & 13.1 & 4.67 & 7.65 & 1.76 & 13.3 & 211 & 1887 & 62 & 17 & 48 \\
\hline Significance & $* *$ & NS & $*$ & $*$ & NS & NS & $*$ & NS & $*$ & NS & NS \\
\hline $\operatorname{LSD}(0.05)$ & 4.5 & -- & 1.43 & 2.07 & --- & $\cdots$ & 114 & --- & 9 & $\cdots$ & --- \\
\hline \multicolumn{12}{|l|}{$\mathrm{pH}$} \\
\hline 4.5 & 18.0 & 12.6 & 5.37 & 2.20 & 1.30 & 15.0 & 259 & 253 & 42 & 15 & 47 \\
\hline 6.5 & 19.3 & 11.5 & 5.74 & 10.25 & 2.25 & 8.4 & 289 & 3169 & 68 & 21 & 37 \\
\hline Significance & NS & NS & NS & $* *$ & $* *$ & $* *$ & NS & $* *$ & $* *$ & $*$ & NS \\
\hline $\mathrm{pH} \times \mathrm{N}$ form & & & & & & & & & & & \\
\hline Significance & NS & NS & NS & NS & NS & NS & NS & NS & $* *$ & NS & NS \\
\hline
\end{tabular}

and Dana, 1984). Soil $\mathrm{NO}_{3}-\mathrm{N}$ levels were high and $\mathrm{NH}_{4}-\mathrm{N}$ levels were low in the original blueberry site, while, in the cranberry bogs sampled, soil $\mathrm{NH}_{4}-\mathrm{N}$ levels were high and $\mathrm{NO}_{3}$ $\mathrm{N}$ levels were low (Table 8). The implication is that 'Northblue' blueberry, because of imposed selection pressures of high $\mathrm{NO}_{3}$ $\mathrm{N}$ in the root zone, has mechanisms to take up and use $\mathrm{NO}_{3}-\mathrm{N}$. In contrast, 'Searles' cranberry, a selection from the wild where $\mathrm{NH}_{4}-\mathrm{N}$ apparently is the dominant $\mathrm{N}$ form, has a limited capacity to efficiently take up and/or use $\mathrm{NO}_{3}-\mathrm{N}$.

Table 8. Comparison of $\mathrm{pH}$ and extractable $\mathrm{NO}_{3}-\mathrm{N}$ and $\mathrm{NH}_{4}-\mathrm{N}$ in a blueberry and cranberry soil at two depths. ${ }^{2}$

\begin{tabular}{cccccc}
\hline \hline & \multicolumn{2}{c}{ Blueberry soil } & & \multicolumn{2}{c}{ Cranberry soil } \\
\cline { 2 - 3 } \cline { 5 - 6 } \begin{tabular}{l} 
Depth \\
\cline { 5 - 6 } \cline { 5 - 6 }
\end{tabular} & \multicolumn{2}{c}{$\mathrm{N}$ form $\left(\mathrm{mg} \cdot \mathrm{kg}^{-1}\right)$} & & $\mathrm{N}$ form $\left(\mathrm{mg} \cdot \mathrm{kg}^{-1}\right)$ \\
\cline { 2 - 3 } & $\mathrm{NO}_{3}-\mathrm{N}^{y}$ & $\mathrm{NH}_{4}-\mathrm{N}$ & & $\mathrm{NO}_{3}-\mathrm{N}$ & $\mathrm{NH}_{4}-\mathrm{N}$ \\
\hline $0-15$ & $4.0 \pm 2.6$ & $0.6 \pm 0.3$ & & $0.4 \pm 0.2$ & $1.6 \pm 0.6$ \\
$15-30$ & $2.8 \pm 1.5$ & $0.4 \pm 0.2$ & & $0.4 \pm 0.3$ & $4.4 \pm 2.3$ \\
\hline
\end{tabular}

${ }^{\mathrm{z}}$ Means of three replications $\pm \mathrm{SD}$ at two sampling dates.

${ }^{y} \mathrm{NO}_{3}-\mathrm{N}$ and $\mathrm{NH}_{4}-\mathrm{N}$ extracted with $2 \mathrm{~N} \mathrm{KCl}$ (1 soil : 5 extractant).
Growth responses of these clones to $\mathrm{pH}$ are less clear. Blueberry growth was severely inhibited at $\mathrm{pH}$ 6.5, whereas cranberry showed only a slightly lower root growth due to high $\mathrm{pH}$. Townsend (1969) also found blueberry growth to be poor at higher solution $\mathrm{pH}$ levels compared to lower levels. For cranberry, previous studies have shown that increasing solution $\mathrm{pH}$ up to 6 increases shoot growth and that further increases in $\mathrm{pH}$ decreased shoot growth (Medappa and Dana, 1970). Both of these clones grow natively in acidic soil environments; however, based on solution culture experiments, 'Searles' cranberry seems to have a greater capacity to grow at a higher $\mathrm{pH}$ than 'Northblue' blueberry.

Effects of $\mathrm{pH}$ and $\mathrm{N}$ form on root color in Ericaceous plants have been reported in previous studies (Peterson et al., 1988; Townsend, 1967, 1969, 1971). Observations of Mn accumulation in roots with high solution $\mathrm{pH}$ and $\mathrm{NO}_{3}-\mathrm{N}$ have led to the hypothesis that root darkening may result from precipitation of hydrated manganese oxide (Peterson et al., 1988; Townsend, 1971). In agreement with these previous reports, $\mathrm{NO}_{3}-\mathrm{N}$ and high $\mathrm{pH}$ resulted in a darkening of blueberry and cranberry 
roots. Furthermore, high root $\mathrm{Mn}$ was associated with-high solution $\mathrm{pH}$, and, to a lesser extent, $\mathrm{NO}_{3}-\mathrm{N}$ (Table 5), suggesting that root-zone $\mathrm{pH}$ and $\mathrm{Mn}$ precipitation play a role in root color.

Root concentrations of Fe were also extremely high in both clones. In contrast, shoot concentrations were as much as 100 times lower. In previous studies with blueberries (Townsend, 1967, 1969), root concentrations of Fe were found to be 20 to 30 times higher than shoot concentrations. With cranberries, Fe was selectively excluded from shoot tissues when present at high external concentrations (Medappa and Dana, 1970). Therefore, the high root $\mathrm{Fe}$ concentrations detected in the present experiment most likely were due to precipitation of iron salts on the root surface.

Using X-ray microanalysis, small crystal-like particles were observed on surfaces of cranberry roots from all treatments. Xray spectra from roots grown in the $\mathrm{NH}_{4}-\mathrm{N} / \mathrm{NO}_{3}-\mathrm{N}$ treatment at $\mathrm{pH} 4.5$ and 6.5 are shown in Figs. 1 and 2. At the low $\mathrm{pH}$, spectra from the particles had elevated levels of Fe and P compared to spectra from root epidermal cells devoid of particles

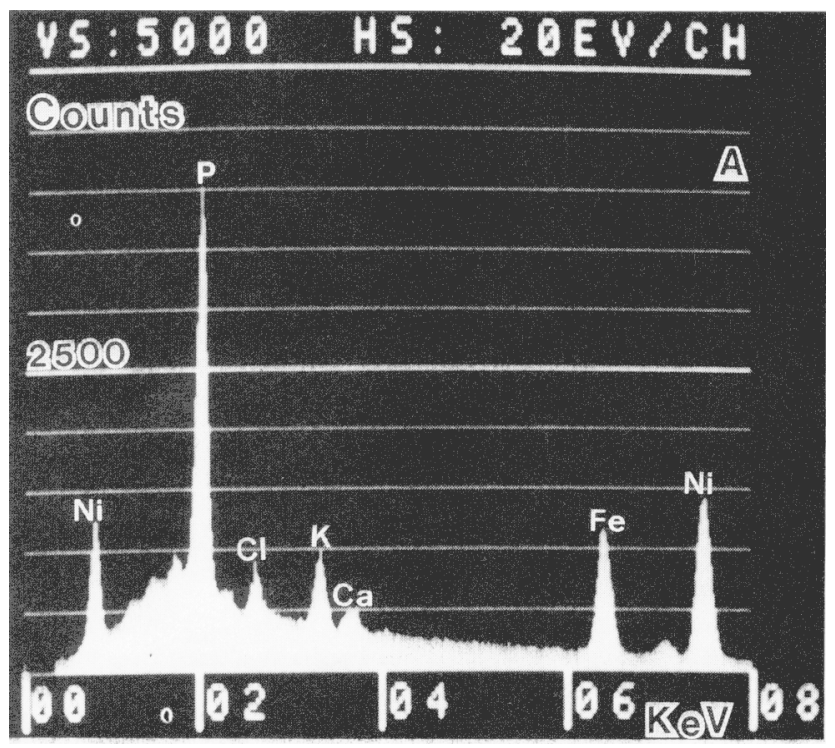

\section{YS: 5000 HS: $20 E V / C H$}

\section{Counts}

B

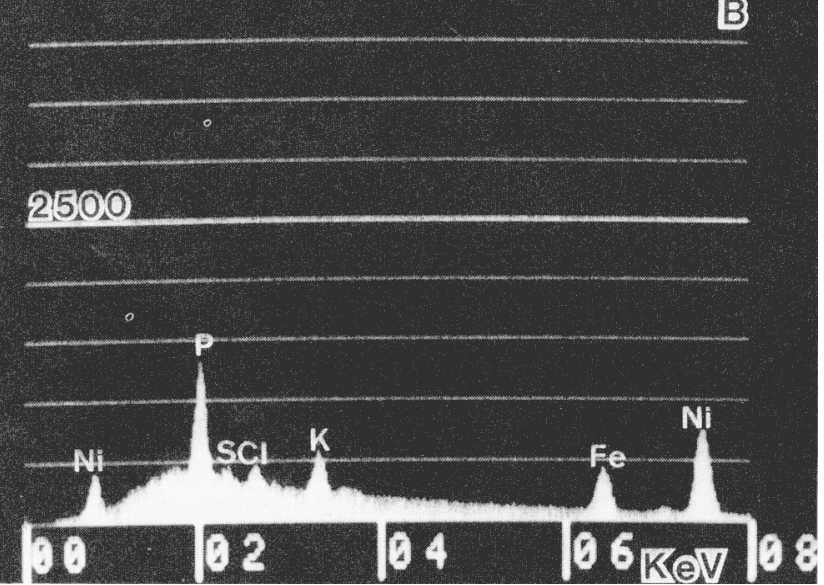

Fig. 1. X-ray microanalysis spectra of 'Searles' cranberry roots from $\mathrm{pH} 4.5, \mathrm{NH}_{4}-\mathrm{N} / \mathrm{NO}_{3}-\mathrm{N}$ treatment indicating relative nutrient levels. (A) Spectrum of crystal-like particle on root surface. (B) Spectrum of epidermal cell surface.
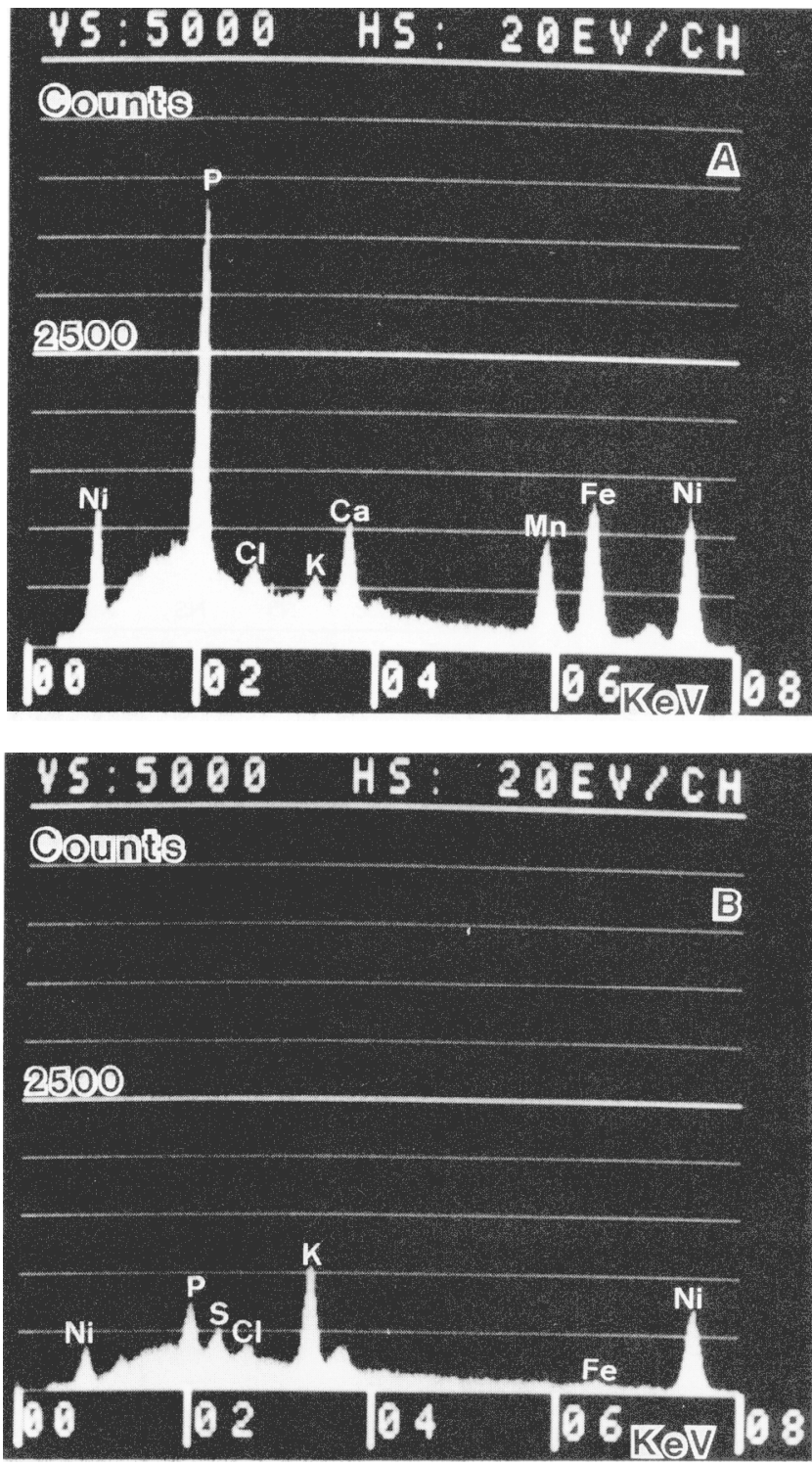

Fig. 2. X-ray microanalysis spectra of 'Searles' cranberry roots from $\mathrm{pH} 6.5, \mathrm{NH}_{4}-\mathrm{N} / \mathrm{NO}_{3}-\mathrm{N}$ treatment indicating relative nutrient levels. (A) Spectrum of crystal-like particle on root surface. (B) Spectrum of epidermal cell surface.

(Fig. 1 A and B). Manganese levels were generally below detection limits of the x-ray analyzer in roots grown at low $\mathrm{pH}$. Similar results were observed at the high $\mathrm{pH}$, except that $\mathrm{Mn}$ was also present in the particles (Fig. 2 A and B). A large portion of the Mn associated with the roots at the high-pH treatment is apparently external to the epidermal cells. Use of EDTA as a chelate for $\mathrm{Fe}$ has been shown to increase precipitation $\mathrm{Fe}$ on the root surface (Chancy and Bell, 1987). Thus, the form of Fe supplied, and the duration ( 7 to 9 months) and dosage (80 $\mu \mathrm{M})$ to which roots were exposed, may have contributed to the Fe phosphate or hydroxide precipitation.

In conclusion, this study has demonstrated that $\mathrm{N}$ form was an important factor in the growth of 'Searles' cranberry, but was less important in the growth of 'Northblue' blueberry. Differences in the $\mathrm{N}$ response of these cultivars may be related to the environments in which they were selected. Conceivably, the variation within each species for $\mathrm{NO}_{3}-\mathrm{N}$ use may account for the varied responses reported in the literature. 


\section{Literature Cited}

Addoms, R.M. and F.C. Mounce. 1932. Further notes on the nutrient requirements and the histology of the cranberry, with special reference to the sources of nitrogen. Plant Physiol. 7:643-656.

Cain, J.C. 1952. A comparison of ammonium and nitrate nitrogen for blueberries. Proc. Amer. Soc. Hort. Sci. 59:161-166.

Carlson, R.M. 1978. Automatic separation and conductimetric determination of ammonia and dissolved carbon dioxide. Anal. Chem. 50:1528-1532.

Carlson, R.M. 1986. Continuous flow reduction of nitrate to ammonia with granular zinc. Anal. Chem. 58:1590-1591.

Chancy, R.L. and P.F. Bell. 1987. Complexity of iron nutrition: lessons for plant-soil interaction research. J. Plant Nutr, 10:963-994.

Dirr, M.A. 1974. Nitrogen form and growth and nitrate reductase activity of the cranberry. HortScience 9:347-348.

Greidanus, T., L.A. Peterson, L.E. Schrader, and M.N. Dana. 1972. Essentiality of ammonium for cranberry nutrition. J. Amer. Soc. Hort. Sci. 97:272-277.

Hammett, L.K. and W.E. Ballinger. 1972. A nutrient solution-sand culture system for studying the influence of $\mathrm{N}$ form on highbush blueberries. HortScience 7:498-500.

Leschyson, M.A. and G.W. Eaton. 1971. Effects of urea and nitrate nitrogen on growth and composition of cranberry vines. J. Amer. Soc. Hort. Sci. 96:597-599.

Luby, J.J., D.K. Wildung, C. Stushnoff, S.T. Munson, P.E. Read, and E.E. Hoover. 1986. 'Northblue', 'Northsky', and 'Northcountry' blueberries. HortScience 21:1240-1242.

Medappa, K.C. and M.N. Dana. 1970. The influence of $\mathrm{pH}, \mathrm{Ca}, \mathrm{P}$ and $\mathrm{Fe}$ on the growth and composition of the cranberry plant. Soil Sci. 109:250-253.
Munter, R.C., T.C. Halverson, and R.D. Anderson. 1984. Quality assurance for plant tissue analysis by ICP-AES. Commun. Soil Sci. Plant Anal. 15:1285-1322.

Oertli, J.J. 1963. Effect of form of nitrogen and $\mathrm{pH}$ on growth of blueberry plants. Agron, J. 55:305-307.

Peet, M.M., C.D. Raper, L.C. Tolley, and W.D. Robarge. 1985. Tomato responses to ammonium and nitrate nutrition under controlled root-zone pH. J. Plant Nutr. 8:787-798.

Peterson, L.A., E.J. Stang and M.N. Dana. 1988. Blueberry response to $\mathrm{NH}_{4}-\mathrm{N}$ and $\mathrm{NO}_{3}-\mathrm{N}$. J. Amer. Soc. Hort. Sci. 113:9-12.

Rorison, I.H. 1986. The response of plants to acid soils. Experiential 42:357-362.

Rufty, T.W., C.D. Raper and W.A. Jackson. 1983. Growth and nitrogen assimilation of soybeans in response to ammonium and nitrate nutrition. Bot. Gaz. 144:466-470.

Salsac, L., S. Chaillou, J. Morot-Gaudry, C. Lesaint, and E. Jolivet. 1987. Nitrate and ammonium nutrition in plants. Plant Physiol. Biochem. 25:805-812.

Stang, E.J. and M.N. Dana. 1984. Wisconsin cranberry production. HortScience 19:478.

Stieber, T. and L.A. Peterson. 1987. Contribution of endogenous nitrogen toward continuing growth in a cranberry vine. HortScience 22:463-464.

Townsend, L.R. 1967. Effect of ammonium nitrogen and nitrate nitrogen, separately and in combination, on the growth of the highbush blueberry. Can. J. Plant Sci. 47:555-562.

Townsend, L.R. 1969. Influence of form of nitrogen and $\mathrm{pH}$ on growth and nutrient levels in the leaves and roots of the lowbush blueberry. Can. J. Plant Sci. 49:333-338.

Townsend, L.R. 1971. Effect of acidity on growth and nutrient composition of the highbush blueberry. Can. J. Plant Sci. 51:385-390. 